\title{
WEATHER IN THE UNITED STATES
}

\section{OENERAL CONDITIONS}

The weather of the month was that appropriate to a normal July; temperature was close to normal in practically all parts of the country; precipitation was irregularly distributed, some areas receiving more than the normal, others less. There were very few destructive storms. - A. J. $H$.

\section{CYCLONES AND ANTICYCLONES}

Twelve low-pressure and eleven high-pressure areas were plotted during the month. None of the Lows became important as storms, and there were no indications of hurricanes in adjacent Atlantic waters. The majority of the HIGHs came from the Canadian interior, but were mostly weak.-W. P. Day.

\section{THE WEATHER ELEMENTS}

By P. C. DAY, in Charge of Division PRESSURE AND WINDS

The general distribution of the atmospheric pressure was not unusual for a midsummer month, though anticyclonic conditions were somewhat more pronounced than cyclonic.

In general there were no cyclones that pursued definite courses over extended distances, nor did they cover large areas, though numerous storms of small area prevailed locally in most districts from the Rocky Mountains eastward, and rains were frequent in the Northeastern and Southeastern States, in portions of the Ohio Valley and near-by areas, and in the central Rocky Mountain region.

At the beginning of the month a cyclone of slight importance as to extent of depression and area involved was passing eastward over the Dakotas and Minnesota, - attended by generally light precipitation, but its influence appears to have extended far to the southward and heavy rains occurred over much of the central Plains, and some rain fell as far south as Texas and Louisiana. This cyclone quickly disappeared but considerable precipitation resulted therefrom during the $2 \mathrm{~d}$ over the Great Lakes. On the $3 \mathrm{~d}$ a barometric depression immediately off the southern New England coast caused local precipitation in that area, and thunderstorms were reported over a considerable area from enstern Texas to the Ohio Valley and southern Appalachian region. On the 5th and 6 th low pressure moving from the northern Rocky Mountains toward Lake Superior caused some local heavy rains in near-by areas on those days and its continued eastward movement on the 7 th and 8 th was attended by rather extensive precipitation from the lower Ohio Valley northeastward to New Fngland, and along the entire Atlantic coast southward to Georgia, continuing locally over the Southeastern States for several days thereafter.

Thunderstorm conditions existed over the middle Plains and to the northeastward on the 12 th to 14 th, and like conditions prevailed locally over wide areas in the eastern half of the country ncar the middle of the month, continuing locally along the Atlantic coast until the end of the second decade.

Moderately low pressure over the lower Lakes on the $22 \mathrm{~d}$ caused general rains from the middle Mississippi Valley northeastward over the Lake region, and thunderstorms were again reported over the Southeastern States.
By the 23d the low pressure had advanced slightly to the eastward and generally rainy conditions existed over the entire Appalachian region, extending later to all Atlantic coast districts.

The latter part of the month had no important cyclonic developments though precipitation of the thunderstorm type occurred over widely scattered areas, becoming somewhat general during the last three days over the interior parts of the country and thence northeastward to New England.

In the far West precipitation was light, as usual, and occurred mainly on the first few days or about the middle of the last decade. In Arizona and adjoining areas the usual summer showers occurred rather frequently in some districts, particularly in the highlands, but in other localities dry conditions existed.

Anticyclones of considerable importance covered the more northern sections on several occasions. That central over the northern Rocky Mountains on the first and moving eastward over the Northern States to the Great Lakes by the 4 th and thence southeast to the middle Atlantic coast by the 6th, was probably the most important, as it was attended by the lowest temperatures of the month over extensive areas. Several other anticyclones crossed the country at intervals but they were not important as to their effect upon the general weather conditions.

The average sea-level pressure was above normal over all parts of the United States and also in Canada as far north as observations are obtainable at present, though the excesses were mainly small save in the Rocky Mountain region.

Compared with the preceding month the pressure was higher in all districts of both the United States and Canada, save from the lower Lakes and northern drainage area of the Ohio eastward to near the Atlantic coast. The excesses were considerable over the Rocky Mountain and adjacent areas.

The general distribution of pressure favored southerly winds over the central and southern portions east of the Rocky Mountains and over the Atlantic Coast States as far north as New England, though in the latter area they were frequently southwest and occasionally from the west. Along the northern border from the Rocky Mountains to the upper Lakes they were mainly from northerly points, and similar winds prevailed generally along the Pacific coast.

Local high winds were of frequent occurrence from the Great Plains eastward and they occurred in all portions of the month. Some were of tornadic character, the most important of these occurring in eastern Kansas on the $16 \mathrm{th}$, where some 16 lives were lost and large property damage resulted. Considerable damage occurred also from hail which was of rather frequent occurrence in some of the States.

The details of the more important storms appear in the table at the end of this section.

\section{TEMPERATURE}

Day to day changes in temperature were mainly unimportant, rarely exceeding $10^{\circ}$ to $15^{\circ}$ in 24 hours, and at no time did the temperature vary greatly from the normal for the period save on a few dates. The first few days had some of the warmest weather of the month, notably on the 1st when the highest temperatures of the month were recorded in portions of the 